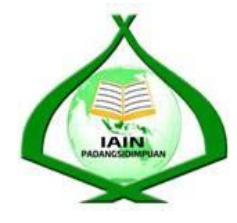

ENGLISH EDUCATION

English Journal for Teaching and Learning

Vol. 07 No. 01 June 2019 page 113 - 126

http://jurnal.iain-padangsidimpuan.ac.id/index.php/EEJ

\title{
Error Translation in Public Sign
}

\section{Sri Minda*}

Institut Agama Islam Negeri (IAIN) Padangsidimpuan

email: sriminda18@gmail.com

\begin{abstract}
This research aims to analize error translation found in public signs written in English such billboard, shops name, and so on. This research also investigates the reasons of the error. This reserach was designed based on descriptive analysis. The data were taken by taking photosof billboard and shops name in Padangsidimpuan for three weeks. After analyzing the data it was found that there are three types of error translation on public signs they are, spelling error, grammatical error, and wrong choice of word. The data showed that $70 \%$ of the total error is spelling error, followed by grammatical error which is $20 \%$ and the lowest percentage is wrong choice of word which is $10 \%$. The reason of these errors due to lack of English knowledge. Most of the owner who made the public signs do not know correct spelling or diction in English.
\end{abstract}

Key Words: error translation; public sign; billboard; spelling error; diction

Abstrak Penelitian ini bertujuan untuk menganalisis jenis error translation yang terdapat pada iklan-iklan publik berbahasa Inggris seperti baliho, merek toko,dan lain-lain dan untuk mengetahui alasan dari error translation pada iklan publik. Jenis penelitian ini adalah analisis deskripsi.Peneliti mengambil data dengan memfoto baliho dan merek nama-nama toko yang ada di Padangsidimpuan selama tiga minggu. Hasil analisi menyatakan bahwa peneliti menemukan tiga jenis error translation pada iklan publik yaitu spelling error, grammatical error, dan wrong choice of word. Data menunjukkan bahwa $70 \%$ dari seluruh total kesalahan adalah spelling error, grammatical error sebanyak $20 \%$ dan persentasi terendah adalah wrong choice of word sebanyak $10 \%$. Kesalahan pada penerjemahan ini dikarenakan akibat para penerjemah atau pedagang tidak tahu ejaan sebenarnya dan tidak banyak tahu tentang bahasa Inggris. Penerjemahan ini dilakukan hanya dengan kebiasaan melihat dan mendengar bahasa Inggris sehari-hari.

Kata kunci: error translation; public sign; billboard; spelling error; diction

\footnotetext{
${ }^{*}$ Corresponding Author : sriminda18@gmail.com
} 


\section{INTRODUCTION}

The development economy promotes English begins to enter into people's lives as an important way to communicate with the world. Since the 2008 Olympic Games, the XVIII World Congress of the International Federation of Translators (FIT) and World's Exposition are on their way, the government is urging the officials to pay more attention to the translation of public sign expressions. Translating the expressions of public signs needs to be standardized in order to enhance the cultural environment of our country and strengthen the communication with the world.

Public signs refer to words and pictures giving information about people's lives in public places in order to inform, indicate, suggest and warn the public. We can see public signs everywhere. Where there is lodging, traveling, entertainment or shopping, there are public signs. Some public signs aim at encouraging customers to consume.

In fact, in the age of globalization, the manufactured products are marketed in countries other than the country of origin. However, non-English speaking audiences will need to know about these products, and they need to understand the benefits and the how-to-use instructions of such products. In this case, globalization in the business world will lead to the need for advertising and the translation of advertising which facilitates global communication among people.

There are some studies investigate the issue of error translating advertisements. The current situation of English translation of these signs is not satisfactory, and various cases of poorly translated English signs present foreign readers with a jumbled meaning. The study was done in analyzing the China's advertisement. There are many mistakes in translation the China language into English. The frequent problems in the translation of public signs degrade China's international status as a major role on the global platform. ${ }^{1}$

The same study also states that many mistranslations on the advertising brochures. He explored the issue of translated advertising brochures in terms of translation strategies and linguistic inaccuracies by examining a corpus of 35

${ }^{1}$ Guo. 2012. Analysis on the English-translation Errors of Public Signs: A fresher approach to contextual advertising. Tianjin University Press 
English-Arabic brochures promoting personal care products. The researcher found that $67 \%$ violating of coherence and $33 \%$ wrong choice of word in term of linguistics inaccuracies. It means that mistranslation of public signs is an emergent issue that needs immediate attention. ${ }^{2}$

Standard English version of public signs that may perform intended functions should at least meet the following basic specifications: correct spelling, brief and concise language style, choice of appropriate words, use of frequent words and the consideration of cultural differences.

Yet, if we look carefully when walking along the streets in the city we live, when we are in stores, parks, hotels etc., it's not difficult to find many problematic translations of public signs in many public places. These mistranslated public signs are just extremely embarrassing when a foreigner encounters them.

Based on the reality, the researcher wanted to investigate kinds of the error translation on public sign and the reason of mistranslation on public sign. Because the bungled English signs that will confuse, mislead, and frustrate the reader.

The scope of this study was limited into the translation of English public sign in Padangsidimpuan. The researcher focused on the error translation on the language use on public sign especially advertisement and to investigate the reason of that mistranslation. The study objects to relate to the problem statements above are finding out the error translation on English public sign especially advertisement and the reason of why the translator made inappropriate translation on the public sign.

The result of this research has significances, theoriticallythe researcher will have more detailed understanding abouttranslation studies, especially translation process from the source language (Indonesian) intotarget language (English) and the appropriateness of translation and also it can be used as reference for those who want to conduct a study in English and Mandailing language. Practically, the lecturer who teaches translation can explain this topic clearly and can improve the students' quality of the translation work.

${ }^{2}$ Khan, Muhammad Muhsin. 1981. Sahih Al-Bukhari. (Arabic-English) Riyadh: Maktabah ar-Riyaad al-Hadeethah. 
Translation is the process of transferring the meaning, content and style from a language to another language in the written form. It is a term which meansreplacing the meaning of thought and ideas from one language to another language, both in written or oral expression, orthographies, sign, or with signs of the deaf. ${ }^{3}$ It is not so complete definition, because the writer just concerns the transferring of thought and idea, the writerdoes not cencern to the form of target language.

Translation is the process of replacing the ideas from one languageto another language with equivalent meaning. The language to be translated is called as Source Language (SL), meanwhile the language tobe translated into called as Target Language (TL). ${ }^{4}$ In translation, the translator must have experience in both of the languages. It means that the translator should be knowledable about the source language and target language.

Translation as a process of reproducing original thought of one language into another language with its equivalents. ${ }^{5}$ In other words, translation is transferring meaning, message, and style both source language and target language. The theory of translation divides the types of elements into six such as reproducing the message, equivalence, natural equivalence, the closest equivalence, the priority of the meaning and the significance of style. ${ }^{6}$

The categories to choose theory in translation are recency and relevance. Recency is the new theory. Relevance is a term which is related to the theory of appropriateness with the research problem.7This study uses Nida and Taber's theory because it is the newer than other theory. Furthermore, it is relevant with the research problem in this study.

${ }^{3}$ Richards, J. ed. (1972). Error analysis: perspectives on second language acquisition. London: Longman Group Limited.

${ }^{4}$ Maclin,A. (1996). Reference guide to English: a handbook of English as a second language. Washington, D.C.: the Materials Branch, English Language Programs Division, United States Information Agency.

${ }^{5}$ Nida, E. A. 1971. Morphology: The Descriptive Analysis of Words. New York. Ann Arborr. The Universityof Michigan.

${ }^{6}$ Newmark, Peter. (1988a). Approaches to Translation. United Kingdom: Prentice Hall International.

${ }^{7}$ Batnag, Aurora. (1980) Translation Commentary. A Special Project submitted to SEAMEO Regional Language Centre, ingapore. 
Kind of translations is various. The differences include the difference of source language and target language's system, the difference of the material text and the difference of the purpose of translation.

Kind of the translation jump into three types such as intra-lingual translation, inter-lingual translation and inter-semiotic translation. ${ }^{8}$

1. Intra-lingual translation deals with, from one text the translator's own interpretation. In this case the translator transfer the written text from one langauge toanother one. For example, Chairil Anwar's poem entitle "Aku" , if it tanslated into another language, the translator tends to use interpretation because it is really hard to transfer the memaning with its equivalences.

2. Inter-lingual translation determines as more ideal translation than Intralingual translation. In this way, the translator change the form of source language and find its form in target language. The translator will not use interpretation in replacing the meaning. Thus, it is a pure real translation. For further explanation, see thefollowing example:

\section{Source language}

Lenyap segala kenangan

Lenyap duka dan sedih

\section{Target language}

all memories disappear

misery and sadness vanish

The source language is literally transfered into target languagewhich is focused on the source language.Semantic translationi iscommonly led into literal translation, but it will bemore complex and detailed and even sometimes more concentrated. ${ }^{9}$ Moreover, it attempts to maintain semantic and syntactic structures and contextual meaning of the source language. ${ }^{10}$

Translation as a general jumps into three types, they are Intra-lingual translation, Inter-lingual translation and inter- semiotic translation. Another

${ }^{8}$ Nida, E. A. 1971. Morphology: The Descriptive Analysis of Words. New York. Ann Arborr. The University of Michigan.

${ }^{9}$ Broeck, Raymond Van Den. (1985). Second Thought on Translation Criticisms. In Manipulation of Literature: Studies in Literary Translation. (ed) Theo Hermans. London: Croom Helson Ltd.

${ }^{10} J a m e s$, C. (1998). Errors in language learning and use. England: Addison Wesley Longman Limited. 
expert of translationcategorizes translation based on the material in the source and target language into four types such as perfect translation, adequate translation, composite translation and scientific and technical translation. ${ }^{11}$

The following are some translation principles often used in the translation of public sign expressions. ${ }^{12}$

a. be easy to understand

b. be definite in meaning

c. be brief

d. be proper in tone

e. use standardized words and avoid Slang language

Public sign is a form of communication for marketing and used to encourage, persuade, or manipulate an audience (viewers, readers or listeners; sometimes a specific group) to continue or take some new action. Most commonly, the desired result is to drive consumer behavior with respect to a commercial offering, although political and ideological advertising is also common. In Latin, ad vertere means "to turn the mind toward. ${ }^{13}$ The purpose of advertising may also be to reassure employees or shareholders that a company is viable or successful. Advertising messages are usually paid for by sponsors and viewed via various traditional media; including mass media such as newspaper, magazines, television commercial, radio advertisement, outdoor advertising or direct mail; or new media such as blogs, websites or text messages.

\section{METHOD}

This study will be done with design of descriptive qualitative. Descriptions are neened because this study aimsto explain in depth the data gained from the field. This studyis considered qualitative because it analyzes the

${ }^{11 B u r l i n g, ~ R . ~ 1992 . ~ P a t t e r n ~ o f ~ L a n g u a g e, ~ s t r u c t u r e, ~ V a r i a t i o n, ~ C h a n g e . ~ S a n d i e g o . ~}$ Academic Press.

${ }^{12}$ Broeck, Raymond Van Den. (1985). Second Thought on Translation Criticisms. In Manipulation of Literature: Studies in Literary Translation. (ed) Theo Hermans. London: Croom Helson Ltd. Longman.

${ }^{13}$ Borg, W.R. and M.O Gall. 1983. Education Research. Broadway. New York. 
written data in public sign in Padangsidimpuan. The appropriateness of translation and reason of mistranslation in public sign will be discuss in detailed.

In this study, translation analysis will be used because it is considered easier to obtain the data than interpretation and the result of translation is better and it will be more accurate than interpretation. Inspite the researcher does not use interpretation in doing this, the result is believed be more accurate.

The researcher took the data from public sign in Padangsdidimpuan for three weeks. These public signs contain name of service to be advertised to the public. The researcher captured the public sign picture found in the street in Padangsidimpuan.In this study, the data was collected by using translation analysis and interview. Moreover, the researcher also uses another instrument in analyzing the data such us dictionary "An Indonesian-English Dictionary", and the book "Understanding and Using English Grammar". It is done to check the meaning, grammatical sentence and equivalent lexical of source and target language that is translated by the translator.

The researcherused documentation technique because the data sources that arein the form of written sourcesare needed.The researcher took some steps in collecting the data. First, theresearcher foundpublic sign with error translation. Second, the researcher read and understands both source and target language's meaning andmessage conveyed on the topic text. Third, the researcheranalyzed the inappropriate translations in theform of the structure, lexical word and the style. In line with the analysis, the researcher didsome interviews to the owner of the public sign to know their reason of writing the translation.

In analyzing the data the researcher used some steps as the following:

1. comparing the original sentence and its translation on the public sign.

2. analyzed the inappropriate translations in theform of the structure, lexical word and the style

3. analyzing the translation procedures used by translatorin translating the sentences from the source language into target language.

4. determining whether the translation of is appropriate. 


\section{RESULT AND DISCUSSION}

Some analizing steps will be applied to get a good result. Firstly, the researchercompared the original word, prhase or sentence on the public sign and its translation is about advertisement. Secondly, the researcher analyzed the translation procedures which was used by translatorin replacing the sentences from the source language into target language. Thirdly, the researcher identified whether the text ofsource and target language are equivalence in the form of meaning, messageand style. Fourthly, the researcher determined whether the translation is appropriate. Fifthly, the researcher discussed with the translator of public sign.Sixth, the researcher edited the data; it means that the researcher read some comments from thetranslator and corrects some mistakes.

\section{The Translation on Public Sign}

The translation on public sign to be analyzed was in English. So, The SL is Indonesia and TL is English. The translation shown in table 1 as follows:

Table 1

The Translation on Public Sign

\begin{tabular}{cll}
\hline No. & \multicolumn{1}{c}{ Source Language } & \multicolumn{1}{c}{ Target Language } \\
\hline $\mathbf{1}$ & Layanan Nyak & Nyak Servics \\
$\mathbf{2}$ & Potongan harga & Discont \\
$\mathbf{3}$ & Penjahit & Tailor \\
$\mathbf{4}$ & Pencucian Sepeda motor & Doorsmeers \\
$\mathbf{5}$ & Pencucian sepeda motor & Dorsmer \\
$\mathbf{6}$ & Penyewaan mobil & Rent car \\
$\mathbf{7}$ & Pewarnaan rambut & High Ligh \\
$\mathbf{8}$ & Catok rambut & Baby list \\
$\mathbf{9}$ & Perabotan Rumahku & My Home Mebel \\
$\mathbf{1 0}$ & Tidak ada benda asing di toilet & No foreign object in toilet \\
\hline
\end{tabular}

There were ten public signs found which contain error translation. Most of the error translation from SL to TL was the spelling error and the rest was the choice of the word in translation and grammatical error in translation. 
The percentage of the error translation of the public sign can be shown in the following table:

Table 2

The Error translation

\begin{tabular}{clll}
\hline No. & Type of error translation & Frequency & Percentage \\
\hline $\mathbf{1}$ & Spelling error & 7 & $70 \%$ \\
2 & Grammatical error & 2 & $20 \%$ \\
3 & Choice of Word error & 1 & $10 \%$ \\
Total & & 10 & $100 \%$ \\
\hline
\end{tabular}

From the percentage, the highest level of translation was I the spelling translation, the data shown that:

a. Spelling error

1. Nyak servics missed a letter which is $e$, it should be translated as services.

2. Discont missed a letter which is $u$, it should be translated as discount

3. Tailor was wrong lettering which $y$ changed by $i$, it should be translated as Taylor.

4. Doorsmeers was wrong because $s$ in the end of the word, it should be no $s$ in it become doorsmeer

5. The same error in Dorsmer, there were two missing letter in that word which $o$ and $e$, it should be Doorsmeer.

6. High ligh missed a letter which is $t$ in word ligh, it shlouls be light

7. My home mebel missed a letter which is $u$ in word mebel, it should be meubel.

b. Grammatical Error

1. Penyewaan mobil in bahasa Indonesia was translate into English become Rent car. This translation is totally wrong because the patter of bahasa Indonesia is different with English. The pattern of Bahasa Indonesia is D-M (Diterangkan-Menerangkan) while English isM-D (menerangkan-diterangkan). For example: 
Schoolbuilding (English)

bangunan sekolah (bahasa

Indonesia)

School explains the use of building

sekolah explains the use of that bangunan

Based on the example,the translation of that is:

$\begin{array}{ccc}\text { SL: Penyewaan } & \text { mobil } \\ : \text { Rent } & \text { car }\end{array} \longrightarrow$ TL: Car rent

c. Catok rambut in Bahasa Indonesia was translated into English as Baby list. The translation has different meaning with the SL which baby list means a list of baby.

\section{Inappropriate Choice of Word}

1. Tidak ada benda asing di toilet in bahasa Indonesia was translated into English as the target language become No foreign object in toilet. The word asing in the SL was translated into foreign in TL. And benda was translated to object. The choice of foreign and object in the sentence seems inappropriate based on the context. The meaning of the SL is it is forbidden to throw anything in the toilet. This message should be transferred into proper language but still has the same message. In this case the translator choose inappropriate word, it should be he use the word trash or rubbish. Because benda asing in SL is referring to sampah. And sampah in TL language is trash/rubbish. So, the translation can be wrote as No trash/rubbish in the toilet.

2. Another way to translate this sentence is by using paraphrase procedure possible to paraphrase the sentence into prohibition sentence or command sentence are needed by the translator. ${ }^{14}$ So, it is better if the sentence Tidak ada benda asing di toilet is translated into Do not throw trash haphazardly or Please, throw the trash on the dustbin.

${ }^{14}$ Newmark, Petere. 1988b. A Textbook of Translation. United Kingdom: Prentice Hall International. 
In line of the analysis, there are some reasons why the translator wrote this kind of error on the public sign. It is prove by the interview done by the researcher to the owner of the public sign itself. The translators of the written language are the owner of the public sign. They stated that they do not know the proper translation in English. In translating the word or phrase, they wrote the translation based on their experience in the society. It means that they transferred the source language to target language only based on what they heard in the society without making any attention to the exact of the written English of the words. Moreover, they clarified that most of people are get used to know the meaning of the word even the written language is wrong. Because they thought that everyone who read that public sign will be understand the message of the language on it.

The finding of this research is that there are three types of error translation on the public sign. All the public sign which analyzed are advertising public sign. The errors found are:

1. Spelling error translation, in this translation many missing on the word. The public sign which analyzed dominantly wrong in the spelling, the percentage of the error is $70 \%$.

2. Grammatical error translation, which is $20 \%$ of the total data found in public sign translation. The mistranslation occurs in the wrong pattern of the phrase. The translator use the same pattern of phrase between source language to target language which actually they have different pattern.

3. Inappropriate choice of word translation, which only $10 \%$ of the total number. The translator of the public sign translated the source language to target language word by word. So, the choice of the word is inappropriate in the target language. 
After analyzing the data presented above. The researcher found that there are three types of error translation by translator in changing the form of the source language to target language. Those are spelling error, grammatical error and Wrong choice of word in translating the SL to TL.

In translating the data above, the most often error translation is the spelling error. The data shows that $70 \%$ of the total number is misspelling. Then, grammatical error is $20 \%$ and the lowest percentage is inappropriate choice of word in translation. The error translations on the public sign occur because the translators do not understand about the target language. They translated it based on what they see and they heard in daily communication. Regardless of their kind, they can be attributed to several reasons such as dealing with two different linguistic domains, lack of correspondence, lack of attention, or technical factors.

Simply, translations sometimes include inaccuracies resulting from mistakes in spelling. Such spelling mistakes may distort the meaning intended by the SL text unless the readers try to guess the intended word depending on the context. However, if the readers have to guess, there will be violation of the advertising brochure genre norms of clarity, simplicity, and directness of message.

After analyzing the frequent errors of the bilingual public signs in Padangsidimpuan, the current situation of the translation of publicity in big cities in Indonesia shows up its deficiency. There is no denying that public signs play an important role in daily life, and their English versions contribute great help and convenience to the foreigners in Indonesia. Additionally, they also have become an effective way to set up Indonesia's international image. The current situation of English translation of these signs is not satisfactory, and various cases of poorly translated English signs present foreign readers with a jumbled meaning. The greater problem is the error in the spelling, grammatical and inappropriate word in translation. Although there are problems existing in the translation of bilingual public signs, it is still delightful to see that the issue has been bought to spotlight by the academic scene, government and even the general public, and it has already become a public concern which arouses a flaming public interest that it should have deserved for long 


\section{CONCLUSION}

After analyzing the data, conclusion are drawn as follows: There are three types of the error translation on the public sign; spelling error, grammatical error and inappropriate choice of word. The reason of mistranslation done by translator on the public sign is attributed to several reasons such as dealing with two different linguistic domains, lack of correspondence, lack of attention, or technical factors.

\section{REFERENCES}

Batnag, Aurora. Translation Commentary. A Special Project submitted to SEAMEO Regional Language Centre, Singapore. Biber, Douglas. Longman Grammar of Spoken and Written English. England: Pearson Education Limited, 1999.

Blaxter, Loraine, et.al, How To Research; Second Edition, (Philadelphia: Open University Press, 1945.

Borg, W.R. and M.O Gall. 1983. Education Research. Broadway. New York. Longman, 1983.

Broeck, Raymond Van Den. Second Thought on Translation Criticisms. In Manipulation of Literature: Studies in Literary Translation. (ed) Theo Hermans. London: Croom Helson Ltd, 1985.

Burling, R. Pattern of Language, structure, Variation, Change. Sandiego. Academic Press, 1992.

Guo. Analysis on the English-translation Errors of Public Signs: A fresher approach to contextual advertising. Tianjin University Press, 2012.

James, C. Errors in language learning and use. England: Addison Wesley Longman Limited, 1998.

Khan, Muhammad Muhsin. Sahih Al-Bukhari. (Arabic-English) Riyadh: Maktabah ar-Riyaad al-Hadeethah, 1981.

Krohn, Robert. English Sentence Structure. America: The University of Michigan, 1971.

Maclin,A. Reference guide to English: a handbook of English as a second language. Washington, D.C.: the Materials Branch, English Language Programs Division, United States Information Agency, 1996.

Newmark, Peter, Approaches to Translation. United Kingdom: Prentice Hall International. 1988a.

A Textbook of Translation. United Kingdom: Prentice Hall International. 1988b. 
Nida, E. A. Morphology: The Descriptive Analysis of Words. New York. Ann Arborr. The University of Michigan, 1971.

Richards, J. ed. (1972). Error analysis: perspectives on second language acquisition, London: Longman Group Limited, 1972.

Salim, Elvin Yunanda. An Analysis of Grammatical Errors in Students' essay of Past Narration Comic, Salatiga: Universitas Kristen Satya Wacana, 2013.

Ur, Penny. Grammar Practice Activities, A practical Guide for Teachers, Cambridge; Cambridge University Press. 1988. 